AperTO - Archivio Istituzionale Open Access dell'Università di Torino

\title{
Management of T4a Laryngeal Cancer
}

\section{This is the author's manuscript}

Original Citation:

Availability:

This version is available http://hdl.handle.net/2318/1625882

since 2022-01-12T13:23:24Z

Published version:

DOI:10.1007/s40136-017-0142-8

Terms of use:

Open Access

Anyone can freely access the full text of works made available as "Open Access". Works made available under a Creative Commons license can be used according to the terms and conditions of said license. Use of all other works requires consent of the right holder (author or publisher) if not exempted from copyright protection by the applicable law. 
This is the author's final version of the contribution published as:

Crosetti, Erika; Caracciolo, Alessandra; Arrigoni, Giulia; Fantini, Marco; Sprio, Andrea E.; Berta, Giovanni N.; Succo, Giovanni. Management of T4a Laryngeal Cancer. CURRENT OTORHINOLARYNGOLOGY REPORTS. None pp: 1-14.

DOI: $10.1007 / \mathrm{s} 40136-017-0142-8$

The publisher's version is available at: http://link.springer.com/10.1007/s40136-017-0142-8

When citing, please refer to the published version.

Link to this full text:

http://hdl.handle.net/ 


\section{Management of T4a laryngeal cancer}

Erika Crosetti, MD PhD³, Alessandra Caracciolo, MD1, Giulia Arrigoni, MD1, Marco Fantini MD1, Andrea E. Sprio, PhD², Giovanni N. Berta, PhD², Giovanni Succo, MD1.

\section{Affiliations:}

${ }^{1}$ Otolaryngology Service, Department of Oncology, San Luigi Gonzaga Hospital, University of Turin, Italy

${ }^{2}$ Department of Clinical and Biological Sciences, University of Turin, Italy

${ }^{3}$ Head and Neck Oncology Service, FPO IRCCS - Candiolo Cancer Institute, Candiolo, Italy

Author to whom correspondence should be sent:

Erika Crosetti MD

Head and Neck Oncology Service, FPO IRCCS - Candiolo Cancer Institute,

Candiolo, Italy

Tel.: + 39 011-70952305

Fax: + 39 011-70952252

E-mail: erikacro73@yahoo.com

Key words: T4 laryngeal cancer, laryngectomy, laryngeal preservation, partial laryngectomy, chemotherapy, radiotherapy

Conflict of interest: There are no competing interests for this article 


\section{Abstract}

Background: Despite the recommendations contained in the guidelines, a general rise in non-surgical treatments and declining use of total laryngectomy has occurred during the last decades, as well as some evidence of declining survival for advanced laryngeal cancer in many countries.

Goal: To compare the results of surgical and non-surgical approach for T4a laryngeal cancer in term of curative effects, complications, and functional results by means of a systematic review of the more recent literature.

Recent findings: Most recent data clearly demonstrate the superiority of total laryngectomy and post-operative radiotherapy, which produce a substantial long-term control and survival rates for patients with $\mathrm{T} 4$ larynx cancer. The most negative prognostic factor is represented by $\mathrm{N}$ status. Open partial laryngectomy, to the light of good and encouraging oncological/functional results, could represents an alternative to total laryngectomy for selected patients affected by laryngeal cancer in specific T4a subcategories, i.e. limited anterior extension. Considering the worse oncologic results, principally in patients with poor general conditions and T4a cancer, non-surgical larynx preservation should only be addressed to carefully selected patients who refused total laryngectomy, characterized by more limited T4a disease, minimal involvement through the cartilage and without pre-treatment derangement of laryngeal functions. 


\section{Introduction}

Laryngeal cancer (LC) is among the most common cancers of the head and neck, with about 110.000 to 130.000 new cases diagnosed worldwide annually, representing the $2 \%$ of the malignant neoplasms and the $60 \%$ of cervico-cephalic tumors [1].

Survival rates of LC patients range from $73-92 \%$ for the early stage disease (I - II) to 50 $64 \%$ for the advanced stage disease (III - IV) [2]. The latter is associated with a high rate of loco-regional relapse and cancer-related death. The overall survival (OS) of advanced stage LC is negatively affected by $\mathrm{T}$ status and the $\mathrm{N}$ status, which have been recognized as independent prognostic factors in the literature [3].

The LC treatment relies on many available therapeutic approaches: the overarching goal of all of them is to maximize survival and, whenever possible, preserve voice and swallowing function. The National Comprehensive Cancer Network (NCCN) Clinical Practice Guidelines in Oncology [4] indicate the follows:

1. patients suffering from $T 1, T 2$ and selected $T 3 L C$ should be initially treated with the aim to preserve the larynx, using transoral laser microsurgery (TLM), partial laryngectomy $(\mathrm{OPHL})$ or radiotherapy $(\mathrm{RT})$

2. patients suffering from T3 $L C$ amenable to total laryngectomy $(T L)$ can of course be treated with up-front surgery but better should be addressed to organ sparing protocol by concurrent chemoradiotherapy (CCRT) or induction chemotherapy followed by radiotherapy (IC-RT) in order to preserve the larynx and its functions.

3. TNM classification system of LC (VII edition) [5] divided T4 into 2 categories: T4a, moderately advanced local disease, defined as tumors invading through the thyroid cartilage and/or invading tissues beyond the larynx (e.g. trachea, soft tissues of neck including deep extrinsic muscle of the tongue, strap muscles, thyroid or esophagus) and T4b, very advanced local disease, not eligible for surgery.

Patients suffering from T4a LC should be treated with up-front TL in the majority of cases, leaving the organ sparing options to selected patients who decline surgery.

For a century until the 1980s, up-front TL was considered the only therapy for patients with locally advanced LC [6].

Although this strategy can provide a good disease loco-regional control (LRC), it is associated with a negative impact on patients' quality of life (permanent tracheostomy and loss of natural voice) [7]. For this reason, organ-sparing protocols, including non-surgical 
options, as chemo-radiotherapy, and surgical options, as TLM or OPHL, have begun to be considered as reliable alternatives to $\mathrm{TL}$.

Starting from 1991, several clinical studies (Table 1) had analyzed organ-sparing potentialities in the non-surgical management of advanced LC, with confident results; consequently, the therapeutic trend for the treatment of advanced laryngeal cancer had progressively shifted from primary TL toward non-surgical organ preservation approaches. The era of chemo-radiation therapy in laryngeal oncology had taken off.

In 1991, the first pivotal study was conducted by the Laryngeal Cancer Study Group of the Department of Veterans Affair (VA). They investigated in good responder patients with locally-advanced LC whether IC-RT could represent a better approach respect to TL followed by post-operative radiotherapy (TL-PORT) in terms of OS and organ sparing. This study showed a new role for chemotherapy in patients with advanced disease, demonstrating that a treatment strategy involving IC-RT could be effective in preserving the larynx in a high percentage of patients, without compromising overall survival [8].

The Radiation Therapy Oncology Group (RTOG 91-11) confirmed the feasibility and the effectiveness of a chemo-radiation approach. In a large trial published in 2003, in fact, RTOG compared the outcomes obtained with cisplatin plus fluorouracil IC-RT, CCRT and RT alone, detecting a higher laryngeal preservation and locoregional control after the treatment with CCRT [9].

The efforts to improve patient quality of life without affecting the OS clearly altered the perception about treatment modalities. Clinical trials, and consequently guidelines that derived from, demonstrated that TL-PORT had better results in terms of OS on T4a tumors with evident progression through cartilage [10,11,4]. Notwithstanding, many countries and institutions perceived the organ preservation protocols as a TL replacement in the treatment of locally advanced LC. Thus, during the last 20 years, TL was increasingly considered just as a salvage surgery after the failure of organ preservation treatments [12]. Countries extensively adopting organ sparing protocols have seen a sharp increase in LC mortality rates, but they have persisted stable or reduced, where TL continued to be the standard treatment for advanced LC [13].

Starting from these considerations, controversies concerning the correct treatments of $\mathrm{T} 4 \mathrm{a}$ LC, and the role of TL as up-front treatment are arguments nowadays deeply felt.

The most recent literature explored these critical issues, bringing arguments in favor of the return to more traditional surgical approaches in the treatment of locally advanced 
laryngeal cancer. Meanwhile, it was highlighted the therapeutic possibility to undergo partial laryngeal surgery for T4 tumors after a rigorous selection of patients.

\section{Recent survey comparing surgical and non-surgical approaches for patients with T4a Larynx cancer}

The larynx loss due to surgical treatment brings several functional morbidities. Thus, it was one of the first cancer sites in the head and neck district to be considered for preservation by the employment on non-surgical therapeutic approaches. This scenario was also spurred by a greater potential of salvage surgery if compared with other cancer sites [14]. In the last five years, several studies (Table 2) compared survival and functional outcomes of patients affected by advanced stage LC (T3 -T4a) and treated distinctly by total laryngectomy and post-operative radiotherapy (TL-PORT), open partial laryngectomy (OPHL), concurrent radio-chemotherapy (CCRT) or RT alone. The main analyzed endpoint token into accounts were overall survival (OS), disease-free survival (DFS), disease specific survival (DSS), locoregional control (LRC), and different functional outcomes (e.g. laryngectomy free survival - LxFS, laryngoesophageal dysfunction free survival - LED, actuarial freedom from laryngectomy - FFL, actuarial freedom from laryngoesophageal dysfunction-free survival - FFLED).

The majority of them detected significant improvements in terms of oncological outcomes (OS, DFS, DSS, and LCR) only for patients affected by T4a LC undergoing TL-PORT, if compared to those treated by CCRT or RT alone. This is in agreement with the Larynx preservation Consensus Panel recommendations for clinical trial [10] that consider patients with $\mathrm{T} 4 \mathrm{a}$ disease as ineligible for laryngeal preservation protocols, and with the recent National Comprehensive Cancer Network (NCCN) Clinical Practice Guidelines in Oncology [4], American Society of Clinical Oncology (ASCO) guidelines [12] and Italian association of Medical Oncology (AIOM) guidelines [11], which recommend up-front TLPORT in T4a glottic and supraglottic LC and listed CCRT and IC as options only if TL is declined.

Nevertheless, some Authors concluded that disappointing results regarding OS of patients with locally advanced stage LC after non-surgical treatment could be due to an etiological shift, leading to a progressive reallocation of cases between the different sites of the larynx [15]. However, these studies were based on long-term analyses of patient cohorts from countries in which employment rate of TL was substantially unchanged and chemo- 
radiotherapy was used in a minority of cases. This situation made them unable to verify the improved survival associated with the TL.

Nowadays, the most recent literature recommends caution in indicating non-operative chemo-radiotherapy to treat patients with T4a LC. Furthermore, when pursued, this challenging option requires both a multidisciplinary case evaluation and a frank discussion about options and expectations with the patient. Critical is, indeed, not only the tumor extent or the laryngeal function prior the treatment, but also the expected tolerance to treatment on the basis of recorded performance and nutritional status, as well as the presence of comorbidities, particularly cardiopulmonary chronic disease that is common in this population [8, 16].

Recent evaluations have highlighted disappointing long-term results in terms of OS regarding different non-surgical organ-sparing protocols. Considering this end-point, in fact, deaths unrelated with LC were interestingly higher after CCRT (30.8\%) if compared with those following IC (20.8\%) or RT (16.9\%) [17]. It was strongly suspected a toxic role in CCRT leading to increasing fatal occurrences. Anyhow further investigations would be necessary to definitively determine the causative differences [17].

Beyond oncologic end-points, some Authors noticed many other disadvantages. First of all, suffering from numerous comorbidities (e.g. low renal and hepatic functions, poor performance status and insufficient compliance) old and very old patients could not tolerate chemo-radiotherapy approaches. Furthermore, in case of locally advanced LC with deranged laryngeal function prior the treatment or large cartilage destruction, any attempt to preserve the larynx by means of RT or CCRT protocols is hazardous. In fact, it should be always provided enough residual laryngeal cartilage to afford a high likelihood of mechanical stability and / or post-therapy regeneration [13, 18-20]. This finding, according to some Authors, associates laryngeal preservation in T4 LC with a high incidence of acute toxicity and disruption in laryngeal function, in term of significant pharyngeal and esophageal edema, fibrosis and stenosis, xerostomia with diminished perception of swallowing functions and aspiration, acute mucositis and dysphagia. Table 3 reported acute and late toxicities observed in the same studies previously mentioned encouraging organ-sparing protocols.

On the other hand, patients undergone TL develop some irrefutable sequelaes: loss of normal voice, swallowing problems, loss of nasal function, altered smell and taste, poor cough, lung function changes, tracheostomal complications, and lifelong functional and psychological consequences [21]. However, the sole preservation of the larynx does not 
guarantee its function. A patient with an intact but functionless larynx may be unable to swallow, with consequently respiratory complications. The quality of life of an individual with complications after a chemo-radiation protocols may be worse than that of a patient who has undergone a successful TL, who is able to eat and to breathe normally and who can talk with the aid of tracheo-esophageal puncture or by esophageal voice [22].

Voice rehabilitation in laryngectomy patients has been achieved in the past with surgical shunts, esophageal speech, electrolarynx devices, and others. Each of these methods has its advantages and disadvantages. However, since the introduction of voice prosthesis, tracheo-esophageal speech with voice prosthesis (T-E speech) is the accepted standard of care in voice rehabilitation after laryngectomy. In fact, it provides a lung-powered speech and, hence, a physiologically better voice quality [23].

Based on these considerations and focusing the attention only on T4a LC, the up-front surgery with post-operative radiotherapy is the best treatment choice.

As indicated by the most adopted worldwide guidelines, TL remains the standard of care, even with the cost of laryngeal organ loss; chemo-radiation protocols are treatment options for the minority of highly selected patients with smaller-volume cancers, intact airway protection and swallowing function, good performance status and inadequate compliance to a surgical option as well as for patients who firmly reject the radical surgery.

\section{Emerging role for partial laryngeal surgery in selected T4 laryngeal cancer}

The same overarching goals of non-surgical organ preservation, meaning to spare the function without compromising the oncological outcome, have always spurred surgeons to look for technical solutions, which brought to a renaissance of conservative laryngeal surgery. Born from the brilliant intuitions of true Pioneers [24-28], this type of surgery has been acknowledged in recent years of multiple published studies (sometimes from large multi-centric series), which gave a significant boost in the understanding of its benefits and drawbacks. In fact, these procedures had proven to be viable options for the management of early-stage LC, but showed reasonable limits especially with advanced-stage cases. The main clinical difficulty in facing advanced-stage tumors lies in preoperative diagnosis, since the efficiency of imaging techniques (CT-scan and MRI) in detecting infiltration of the thyroid cartilage does not achieve a total diagnostic accuracy [29]. Radical control of disease by a transoral approach (TLM and TORS) cannot be achieved when the lesion involves the laryngeal framework and/or when it tends to grow outside the laryngeal box 
[30, 31]. In fact, anterior encroachment of the thyroid cartilage, crico-thyroid or thyro-hyoid membranes makes the tumor at risk of persistence after TLM even when removals of a cartilage fragment or its extensive vaporization is carried out. Therefore, Peretti and colleagues stated that involvement of the posterior paraglottic space with encroachment of the crico-arytenoid joint and infiltration of the laryngeal framework negatively influence both oncological and functional results, thus limiting the role of TLM to anecdotal cases [32]. Supracricoid laryngectomy and the more recent supratracheal laryngectomy emerged as options for these advanced cancers inasmuch as they still achieve acceptable levels of locoregional control rate and contextually allow the maintenance of a functional larynx.

The factors that must be taken into account before offering the OPHL option to a patient suffering from locally advanced LC are diagnosis of a tumor belonging to favorable Trelated disease subsets, performance and functional status of the patient, presence of comorbidities, compliance to a sometimes demanding rehabilitation protocol, plausible need of adjuvant RT.

A multidisciplinary team evaluation, in a high-experienced Center, as well as an accurate diagnostic work-up resulting from the strong collaboration with Radiologists, are the key to achieve good functional outcomes and minimize the risk of recurrence development and the consequent need of salvage laryngectomy, albeit in a limited number of LC in stage T4a [33].

Despite many T4a cases had been successfully treated with OPHL and had been reported on single institution series (Table 4), the current evidence-based guidelines do not suggest their employment for the management advanced LC cases, even when the patient refuses the radical surgery.

Recently, Succo et al. carefully analyzed results achieved in different subcategories of cT3 and CT4a LC treated with OPHL, which were conducted using the principle of a modular approach. The Authors stated that glottic or supraglottic T4a tumors with full-thickness involvement of the thyroid lamina and/or minimal extralaryngeal extension, but not interesting the posterior paraglottic space and not affecting the mobility of the arytenoid, are those amenable to be treated by OPHL, showing the greater probability of success [34]. The principle underlying the modular approach means that the resection is always prepared in standard mode and the larynx is opened from the side less affected by disease. At this point, under visual control, the sub-sites involved are removed and the radicality checked by the frozen sections. 
In the clinical practice, such cases are the same that current guidelines consider as amenable to non-surgical organ sparing protocol, if the patient refuses the TL. The choice of OPHL with a modular approach instead of CCRT in favorable disease subsets could be considered to be viable not only in prognostic terms, but also as functional results, e.g. a reduction in the number of total laryngectomies.

Furthermore, Authors stated also that the radicality is the same achievable with more demolitive interventions, but the selection of patients must be made very carefully. Indeed, at the end of the work-up, the surgeon must be able to ensure safe margins with sufficient certainty, thus avoiding an up-front TL.

\section{Salvage surgery in locally advanced laryngeal cancer}

With the increasing use of chemoradiation as primary treatments also for advanced LC, the loco-regional complications related to failure of these treatments have increased in term of persistent or recurrent disease, laryngeal dysfunction or radionecrosis and severe neck fibrosis [35].

Despite endoscopy and the availability of modern imaging studies, diagnosis of recurrent or persistent tumor may be difficult. The main hurdles reside in: different growth pattern of radio-recurrent LC with respect to that of primary carcinoma, multiple tumor foci localized below an intact mucosa that are masked by edema and fibrosis, confused patient reported symptoms, and impaired laryngeal mobility [36].

In this scenario, salvage surgery represented the only therapeutic weapon available (Table 5). Regarding the advanced LC, salvage TL remains the gold standard, whereas the employment of organ-sparing protocols such as the OPHL could be considered anecdotal. In case of salvage after CCRT failure, there is no reason to debate about the indication of TL.

Salvage TL is certainly more prone to complications as compared to the up-front one. Evidences from the literature reported that complications after salvage TL are higher in patients undergoing CCRT than in patients treated by RT alone. In fact, chemotherapy deteriorates general health, nutritional and performance status of the patient. Furthermore, exacerbating the obliterative endoarteritis and fibrosis induced by radiation in local tissues, it participates to the creation of micro-vascular damage with tissue hypoxia and impaired wound healing [37]. 
The most common major complication of TL, and in particular in case of salvage one, is pharyngocutaneous fistula (PCF).

To avoid the PCF complications, several studies analyzed the role of "onlay" vascularized flap reconstruction with the rationale to incorporate no-irradiated well vascularized tissue to aid hypoxic tissues and consequently wound healing, reinforce the pharyngeal repair site or augment the circumference of the neopharynx. The incidence of PCF is higher after primary closure than after closure with the interposition of a well vascularized flap (Table $6)$.

The salivary bypass tube is another useful device with positive results in reducing the risk of PCF. In fact, it can be used to stent the reconstruction, calibrate the new digestive tract, and decrease salivary exposure of the anastomotic suture line. Consequently, the pharyngoesophageal reconstruction rapidly heals and the rate of fistula and stricture decreases [38, 39].

However, the morbidity associated with a PCF is undoubtedly greater, thus supporting the aphorism that "prevention is better than any subsequent management and treatment of PCF" [31].

\section{Difficulties in assessing long term quality of life and laryngeal function}

Following the extensive application of non-surgical preservation protocols in the treatment of locally advanced LC, the need to identify functional endpoints able to reflect more closely the aspects of the real quality of life after treatment arose. In fact, despite side effects correlated with TL are evident (decrease in all communication related parameters), those induced by chemo-radiotherapy on life quality and functional outcomes (e.g. swallowing) may not always be correlated with an anatomically preserved larynx [40]. Findings concerning functional outcomes from retrospective series are limited by the lack of consistent / uniform data collection, instrumental swallowing evaluation, and patientreported outcomes with validated metrics [13].

In 2009, the Larynx Preservation Consensus Panel [10] identified four composite functional/mortality endpoints in designing larynx preservation trials: 1) LED: laryngoesophageal dysfunction free survival (any death, local disease recurrence, salvage total laryngectomy, tracheotomy and/or feeding tube placement/persistence after 2 years as an event, censoring all others); 2) LxFS: laryngectomy-free survival (the date of salvage or completion total laryngectomy or the date of death, censoring all others); 3) FFL: 
actuarial freedom from laryngectomy (the date of salvage or completion total laryngectomy, censoring all others); and 4) FFLED: actuarial freedom from laryngoesophageal dysfunction (local disease recurrence, salvage total laryngectomy, tracheotomy and/or feeding tube placement/persistence after 2 years as an event, censoring all others including deaths).

The limited number of patients available for long-term effect analysis, due to the low OS after CCRT, and the lack of correlation between patients' perceptions and objective studies resulted in a reduced statistical power, and highlighted the importance of documenting swallow function before, during, and after chemo-radiation treatment [31]. Therefore, it is currently not possible to draw an accurate picture of the real benefits of the laryngeal preservation in terms of quality of life. In the RTOG study, severe late toxicity was reported in $43 \%$ of patients at the long-term analysis [17]. Anyhow, further investigations with properly designed studies specifically addressing laryngeal function are needed.

Analyzing the telephone intelligibility of LC patients undergoing different therapeutic approaches, Crosetti et al. [41] recently found that more aggressive surgery as well as chemo-radiotherapy correlated with significantly poorer outcomes. Otherwise, TLM or RT alone ensured the best telephonic voice intelligibility. Intermediate-advanced $T$ stages at diagnosis also showed significantly poorer intelligibility outcomes, suggesting that $T$ stage represents an independent negative prognostic factor for voice intelligibility after treatment.

\section{Conclusions}

After several years in which TL seemed to fade, it returned to great actuality.

Long-term survival is achievable for patients with T4a LC and the most negative prognostic factor is represented by $\mathrm{N}$ status. Currently new strong evidences are confirming the role of TL as up-front treatment for advanced LC or salvage treatment in case of organ sparing protocols' failure.

CCRT option presents worse results in terms of oncological and functional rates, principally in T4a cancers and in patients with poor general conditions. Therefore, nonsurgical laryngeal preservation should be addressed to carefully selected patients who refused TL, characterized by more limited T4 disease, minimal involvement through the cartilage without derangements of laryngeal function prior the treatment. 
OPHL, to the light of good and encouraging oncological results, could represents an alternative to TL only for selected patients affected by LC in specific T4 subcategories (in particular for those with anterior extension).

Nowadays, however, TL-PORT remains the gold standard of treatment in locally advanced LC, with stable and acceptable results in terms of oncological, functional and life quality outcomes. 
Table 1 Studies analyzing organ sparing protocols

\begin{tabular}{|c|c|c|c|c|c|}
\hline $\begin{array}{l}\text { Author - year } \\
\text { publication }\end{array}$ & $\mathrm{N}^{\circ}$ of patients & $\begin{array}{l}\text { Cancer site and } \\
\text { staging }\end{array}$ & Treatment modalities & LP & os \\
\hline VALCSG, 1991 [8] & $332 \mathrm{pz}$ & Larynx, III-IV & $\begin{array}{l}P F->R T \text { vs } \\
S \rightarrow R T\end{array}$ & $64 \%$ & $68 \% / 2$ ys \\
\hline EORTC 24891 [42] & 202 pz, & $\begin{array}{l}\text { Hypo pharynx, } \\
\text { II-IV }\end{array}$ & $\begin{array}{l}P F->R T \text { vs } \\
S \rightarrow R T\end{array}$ & $22 \% / 5$ ys & $\begin{array}{l}-\mathrm{PF} \rightarrow \mathrm{RT} 38 \% / 5 \text { ys } \\
-\mathrm{S} \rightarrow \mathrm{RT} 33 \% / 5 \text { ys }\end{array}$ \\
\hline RTOG 91,11 [17] & $547 \mathrm{pz}$ & Larynx, III-IV & $\begin{array}{l}\text { PF } \rightarrow \text { RT vs } \\
\text { CRT vs } \\
\text { RT }\end{array}$ & $\begin{array}{l}\text { - PF }>\text { RT } 71 \% / 5 \text { ys } \\
\text { - CRT } 84 \% / 5 \text { ys } \\
\text { - RT } 66 \% / 5 y s\end{array}$ & $\begin{array}{l}\text { - PF }>\text { RT } 59 \% / 5 \text { ys } \\
\text { - CRT } 55 \% / 5 \text { ys } \\
\text { - RT } 54 \% / 5 y s\end{array}$ \\
\hline $\begin{array}{l}\text { GORTEC 2000-01 } \\
{[44]}\end{array}$ & $213 p z$ & $\begin{array}{l}\text { Larynx, } \\
\text { Hypo pharynx, III-IV }\end{array}$ & $\begin{array}{l}P F \rightarrow R T \text { vs } \\
T P F \rightarrow R T\end{array}$ & $\begin{array}{l}-\mathrm{PF} \rightarrow>\text { RT } 57 \% / 3 \text { ys } \\
-\mathrm{TPF} \rightarrow>\text { RT } 70 \% / 3 \text { ys }\end{array}$ & $\begin{array}{l}-\mathrm{PF} \rightarrow \mathrm{RT} 60 \% / 3 \text { ys } \\
-\mathrm{TPF} \rightarrow \mathrm{RT} 60 \% / 3 \text { ys }\end{array}$ \\
\hline $\begin{array}{l}\text { EORTC 24954- } \\
22950 \text { [45] }\end{array}$ & $450 \mathrm{pz}$ & $\begin{array}{l}\text { Larynx, } \\
\text { Hypo pharynx, III-IV }\end{array}$ & $\begin{array}{l}\mathrm{PF} \rightarrow \mathrm{RT} \text { vs } \\
\mathrm{aPF} \rightarrow \mathrm{RT}(6 \mathrm{w})\end{array}$ & $\begin{array}{l}\text { - PF } \rightarrow \text { RT } 48 \% / 5 y s \\
\text { - aPF }>\text { RT }(6 w) 52 \% / 5 y s\end{array}$ & $\begin{array}{l}\text { - PF } \rightarrow \text { RT } 53 \% / 5 y s \\
\text { - aPF } \rightarrow \text { RT }(6 w) 60 \% / 5 y s\end{array}$ \\
\hline TREMPLIN [47] & $153 \mathrm{pz}$ & $\begin{array}{l}\text { Larynx, } \\
\text { Hypo pharynx, III-IV }\end{array}$ & $\begin{array}{l}\text { TPF }>\text { CRT vs } \\
\text { TPF }>\text { Cet+RT }\end{array}$ & $\begin{array}{l}\text { - TPF }->\text { CRT } 93 \% 3 \text { months } \\
\text { - TPF -> Cet+RT } 93 \% 3 \text { months }\end{array}$ & $\begin{array}{l}\text { - TPF } \rightarrow \text { CRT } 85 \% 1,5 \text { ys } \\
\text { - TPF }>\text { Cet+RT } 86 \% 1,5 \text { ys }\end{array}$ \\
\hline PRADES [48] & $71 \mathrm{pz}$ & Pyriform sinus, III-IV & $\begin{array}{l}\mathrm{PF} \rightarrow \mathrm{S} \text { or RT vs } \\
\mathrm{P}-\mathrm{RT}\end{array}$ & $\begin{array}{l}\text { - PF ->S } 68 \% \% 2 \text { ys } \\
\text { - RT vs P-RT } 92 \% / 2 \text { ys }\end{array}$ & $\begin{array}{l}\text {-PF }>\text { S DFS } 36 \% \% 2 \text { ys } \\
\text { - RT vs P-RT DFS } 41 \% / 2 \text { ys }\end{array}$ \\
\hline
\end{tabular}

$\mathrm{YS}=$ years, $\mathrm{S}=$ surgery, $\mathrm{LP}=$ laryn $\times$ preservation, $\mathrm{OS}=$ overall survival, $\mathrm{DFS}=$ disease free survival, $\mathrm{LFS}=$ laryngectomy free-survival, $\mathrm{CRT}=$ chemo radiation, $\mathrm{PF}=$ platinum-fluorouracil, $\mathrm{T}=\mathrm{T}$ axotere, Cet $=$ Cetuximab 
Table 2 Studies analyzing total laryngectomy and organ-sparing protocols for T3-T4a laryngeal cancer

\begin{tabular}{|c|c|c|c|c|c|c|c|c|c|}
\hline Author year & $\begin{array}{l}\text { Type of } \\
\text { study }\end{array}$ & $\mathbf{N}$ & $\begin{array}{l}\text { Cancer } \\
\text { staging }\end{array}$ & Treatment & os & DSS e DFS & LRC & LP , LEDFS & Conclusions \\
\hline $\begin{array}{l}\text { Bussu, } 2013 \\
\quad[49]\end{array}$ & $\begin{array}{l}\text { Retrospective } \\
\text { cohort study }\end{array}$ & 166 & T3-T4a & $\begin{array}{l}\text { TL, OPHL, } \\
\text { CRT }\end{array}$ & $\begin{array}{l}\text { T4a 3 ys - TL 78\% } \\
\text { - OPHL 68\% } \\
\text { - CRT 54\% }\end{array}$ & $\begin{array}{l}\text { DSS } \\
87 \% / 2 y s\end{array}$ & & $\begin{array}{l}\text { T3+T4a: } \\
\text { CRT 45\% } \\
\text { OPHL 77\% }\end{array}$ & $\begin{array}{l}\text { In whole series no stat sign in } \\
\text { the } 3 \text { arms for OS and DSS. }\end{array}$ \\
\hline $\begin{array}{l}\text { Francis, } 2014 \\
\quad[20]\end{array}$ & $\begin{array}{l}\text { Retrospective } \\
\text { cohort study } \\
\text { and review }\end{array}$ & $\begin{array}{l}108 \\
24 \\
\text { studies }\end{array}$ & T4a & TL, RT, CRT & $\begin{array}{l}81 \% / 2 \text { ys } \\
60 \% / 5 \text { ys } \\
\text { Review: } \\
\text { / 2aa: } \\
\text { - LT } 30-100 \% \\
\text { - RT } 12-21 \% \\
\text { - CRT } 30-65 \%\end{array}$ & & & & $\begin{array}{l}\text { Primary TL provides a high } \\
\text { survival rate for T4a. } \\
\text { High rate of laryngeal } \\
\text { dysfunction after CRT. }\end{array}$ \\
\hline $\begin{array}{l}\text { Dziegielewski, } \\
2012[50]\end{array}$ & $\begin{array}{l}\text { Longitudinal } \\
\text { cohort study }\end{array}$ & 258 & $\mathrm{~T} 3, \mathrm{~T} 4$ & $\begin{array}{l}\text { TL- } \\
\text { PORT/CT, } \\
\text { RT, CRT }\end{array}$ & $\begin{array}{l}\text { 2ys -5ys T3: } \\
- \text { TL- PORT /CT } 2 \text { ys } \\
89 \% \\
5 \text { ys } 70 \% \\
\text { - RT } 2 \text { ys } 48 \% \\
5 \text { ys } 18 \% \\
\text { - CRT } 2 \text { ys } 66 \% \\
5 \text { ys } 52 \% \\
\text { OS / } 2 \text { e } / 5 \text { aa T4a: } \\
\text { - TL-PORT/CT } 2 \text { ys } \\
60 \% \\
5 \text { ys } 49 \% \\
\text { - RT } 2 \text { ys } 12 \% \\
5 \text { ys } 5 \% \\
\text { - CRT } 2 \text { ys } 32 \% \\
5 \text { ys } 16 \%\end{array}$ & $\begin{array}{l}\text { DFS / 2ys T3: } \\
\text { - TL-PORT/CT } \\
94 \% \text { LRC - 0\% LP } \\
\text { - RT } \\
66 \% \text { LRC - } 28 \% \text { LP } \\
\text { - CRT } \\
\text { LRC 53\% LCR - } 48 \% \\
\text { LP } \\
\text { DFS/ 2ys T Ta: } \\
\text { - TL-PORT/CT } \\
67 \% \text { LRC - } 0 \% \text { LP } \\
\text { - RT } \\
30 \% \text { LRC - 3\% LP } \\
- \text { CRT } \\
54 \% \text { LRC - } 29 \% \text { LP }\end{array}$ & & & $\begin{array}{l}\text { TL-R/CT provides superior } \\
\text { survival for T3 and T4a LC } \\
\text { versus RT or CRT. }\end{array}$ \\
\hline $\begin{array}{l}\text { Grover, } 2014 \\
{[51]}\end{array}$ & $\begin{array}{l}\text { Retrospective } \\
\text { cohort study }\end{array}$ & 969 & T4a & $\begin{array}{l}\text { TL-PORT } \\
\text { and LP-CRT }\end{array}$ & $\begin{array}{l}\text { Median OS: } \\
\text { - TL-PORT } 61 \\
\text { months } \\
\text { - LP-CRT } 39 \text { months }\end{array}$ & & & & $\begin{array}{l}\text { Patients with T4a LC receiving } \\
\text { LP-CRT had more advanced } \\
\text { nodal disease and worse OS. } \\
\text { Previous studies of (non-T4a) } \\
\text { locally advanced LC showing } \\
\text { no difference in OS between } \\
\text { LP-CRT and TL may not apply } \\
\text { to T4a disease. }\end{array}$ \\
\hline $\begin{array}{l}\text { Timmermans, } \\
2014[19]\end{array}$ & $\begin{array}{l}\text { Retrospective } \\
\text { cohort study }\end{array}$ & 182 & $\begin{array}{l}\text { T3 and } \\
\text { T4 }\end{array}$ & $\begin{array}{l}\text { TL-PORT } \\
\text { (91\% T4), } \\
\text { RT, CRT }\end{array}$ & $\begin{array}{l}\text { OS / } 5 \text { ys T3: } \\
\text { - TL-PORT } 49 \% \\
\text { - RT } 47 \% \\
\text { - CRT } 45 \% \\
\text { OS / } 5 \text { ys T4a: } \\
\text { - TL-PORT 48\% } \\
\text { - RT } 34 \% \\
\text { - CRT } 42 \% \\
\text { - } 42 \% \text {....... }\end{array}$ & & $\begin{array}{l}\text { T3+T4a: } \\
\text { - TL-PORT } \\
87 \% \\
\text { - RT } 65 \% \\
\text { - CRT } 76 \%\end{array}$ & & $\begin{array}{l}\text { No differences in survival. } \\
\text { T3 : > CRT } \\
\text { T4: > TL-PORT }\end{array}$ \\
\hline $\begin{array}{l}\text { Timmermans, } \\
2015[52]\end{array}$ & $\begin{array}{l}\text { Population } \\
\text { based study }\end{array}$ & $\begin{array}{l}2072 \mathrm{~T} 3 \\
\text { and } \\
1722 \mathrm{~T} 4\end{array}$ & T3-T4 & $\begin{array}{l}\text { TL- } \\
\text { PORT/CT, } \\
\text { RT and CRT }\end{array}$ & $\begin{array}{l}\text { OS / } 5 \text { ys T3: } \\
\text { - TL-PORT/CT } 49 \% \\
\text { - RT 47\% } \\
\text { - CRT 45\% } \\
\text { OS / } 5 \text { ys T4a: } \\
\text { - TL-PORT/CT 48\% } \\
\text { - RT 34\% } \\
\text { - CRT 42\% }\end{array}$ & & & $\begin{array}{l}\text { LFI T3: } \\
\text { - RT } 81 \% \\
\text { - CRT } 77 \% \\
\\
\text { LFI T4a: } \\
\text { - RT } 81 \% \\
\text { - CRT } 87 \%\end{array}$ & $\begin{array}{l}\text { For T4 disease, TL-PORT } \\
\text { showed the best survival }\end{array}$ \\
\hline $\begin{array}{l}\text { Timme, } \\
2015[53]\end{array}$ & $\begin{array}{l}\text { Retrospective } \\
\text { cohort study }\end{array}$ & 71 & T3 - T4 & $\begin{array}{l}\text { TL or PL, } \\
\text { CRT }\end{array}$ & $\begin{array}{l}\text { 15 ys T3: } \\
\text { - TL or PL } 41 \% \\
\text { - CRT } 40 \% \\
\text { 15 ys T4a: } \\
\text { - TL or PL } 54 \% \\
\text { - CRT } 53 \%\end{array}$ & & & $\begin{array}{l}\text { LP total CRT } \\
79 \% \\
\text { LEDFS } 40 \% \\
\text { T3, 33\% T4a }\end{array}$ & $\begin{array}{l}\text { CRT : high rate of laryngeal } \\
\text { and oesophageal dysfunction. }\end{array}$ \\
\hline $\begin{array}{l}\text { Rosenthal, } \\
2015 \text { [14] }\end{array}$ & $\begin{array}{l}\text { Retrospective } \\
\text { cohort study }\end{array}$ & $221 \mathrm{pz}$ & T4a & $\begin{array}{l}\text { TL-PORT } \\
\text { and LP-CRT }\end{array}$ & $\begin{array}{l}\text { median OS } \\
\text { - TL-PORT } 47-48 \\
\text { months } \\
- \text { LP } 38 \text { months }\end{array}$ & $\begin{array}{l}\text { DSS/5 ys } \\
\text { - TL-PORT 60\% } \\
\text { - LP 48,5\% }\end{array}$ & $\begin{array}{l}\text { ys : } \\
\text { - TL-PORT } \\
84 \% \\
\text { - RT } 63 \%\end{array}$ & & $\begin{array}{l}\text { TL-PORT can produce } \\
\text { substantial long-term cancer } \\
\text { control and survival rates for } \\
\text { patients with T4 larynx cancer. }\end{array}$ \\
\hline Luo, 2015 [54] & $\begin{array}{l}\text { Meta-analysis } \\
\text { and review }\end{array}$ & $2013 \mathrm{pz}$ & T3-T4a & $\begin{array}{l}\text { TL-PORT, } \\
\text { IC-RT, CRT, } \\
\text { RT alone }\end{array}$ & $\begin{array}{l}\text { OS: } \\
\text { - TL-PORT } 66 \% \\
\text { - IC-RT } 60,8 \% \\
\text { - CRT } 61 \% \\
\text { - RT alone } 71,6 \%\end{array}$ & $\begin{array}{l}\text { DFS: } \\
\text { - TL-PORT } 56,6 \% \\
\text { - IC-RT } 41 \% \\
\text { - CRT } 44,9 \% \\
\text { - RT alone } 57,8 \% \\
\text { DSS } 55-70 \% \% 5 y \text { s. } \\
\text { - }\end{array}$ & & & $\begin{array}{l}\text { RT alone better OS, DFS, and } \\
\text { LFS in patients with locally } \\
\text { advanced LC. TL }>\text { DFS, but OS } \\
\text { were similar across the different } \\
\text { larynx-preserving treatments } \\
\text { and TL. }\end{array}$ \\
\hline $\begin{array}{l}\text { Rodrigo, } \\
2015 \text { [55] }\end{array}$ & & $80 \mathrm{pz}$ & T3-T4a & TL & OS/5 ys $55 \%$ & DSS / 5 ys $72 \%$ & & & $\begin{array}{l}\text { TL is an effective treatment for } \\
\text { the management of patients } \\
\text { with locally advanced LC }\end{array}$ \\
\hline $\begin{array}{l}\text { Gorphe, } \\
2016[56]\end{array}$ & $\begin{array}{l}\text { Retrospective } \\
\text { cohort study }\end{array}$ & $100 \mathrm{pz}$ & $\mathrm{T} 4 \mathrm{a}$ & TL-PORT & $\begin{array}{l}\text { OS/ } 2 \text { ys } 65 \% \\
\text { OS/ } 5 \text { ys } 52,4 \% \\
\text { OS/ } 10 \text { ys } 33,3 \%\end{array}$ & $\begin{array}{l}\text { DFS/ } 2 \text { ys } 55 \% \\
\text { DFS/ } 5 \text { ys } 42,6 \% \\
\text { DFS } / 10 \text { ys } 31,8 \%\end{array}$ & $\begin{array}{l}\mathrm{LCR} / 2 \text { ys } \\
77 \% \\
\text { LCR/ } 5 \text { ys } \\
74 \% \\
\text { LCR } / 10 \text { ys } 65,9\end{array}$ & & $\begin{array}{l}\text { Surgery for T4a larynx cancer } \\
\text { remains a standard of care }\end{array}$ \\
\hline Fu, 2016 [1] & Meta-analysis & & $\begin{array}{l}\text { T3 and } \\
\text { T4a }\end{array}$ & $\begin{array}{l}\text { TL-PORT } \\
\text { and LP-CRT }\end{array}$ & $\begin{array}{l}\text { OS/2 ys } \\
\text { - TL-PORT } 78,8 \% \\
\text { - LP-CRT } 52,9 \% \\
\text { OS/5 ys } \\
\text { stat sign only T4a }\end{array}$ & & $\begin{array}{l}\text { LC/2 ys } \\
- \text { TL-PORT } \\
76 \% \\
\text { - LP-CRT } \\
54,6 \% \\
\text { LC/5 ys } \\
\text { Not stat sign } \\
\text { No... }\end{array}$ & & $\begin{array}{l}\text { TL-PORT significant advantage } \\
\text { in OS and LCR T4a laryngeal } \\
\text { cancer }\end{array}$ \\
\hline $\begin{array}{l}\text { Sanabria } \\
2016[57]\end{array}$ & Review & & $\begin{array}{l}\text { T3 and } \\
\text { T4a }\end{array}$ & TL, CRT & $26 \%$ & & & & $\begin{array}{l}\text { Evidence supports total } \\
\text { laryngectomy for patients with } \\
\text { T4 cancers. T3 possible CRT }\end{array}$ \\
\hline $\begin{array}{l}\text { Al-Gilani, } \\
2016[58]\end{array}$ & $\begin{array}{l}\text { Retrospective } \\
\text { cohort study }\end{array}$ & $487 \mathrm{pz}$ & T3 & $\begin{array}{l}\text { Surgery vs } \\
\text { LP-CRT }\end{array}$ & $\begin{array}{l}\text { OS 5/ ys } \\
\text { - surgery } 41 \% \\
\text { - CRT 36\% }\end{array}$ & & & & $\begin{array}{l}\text { OS > in pz with T3 glottic SCC } \\
\text { who underwent surgery } \\
\text { compared with a nonsurgical } \\
\text { treatment. Furthermore, } \\
\text { adjuvant and nonsurgical } \\
\text { treatment result in a } \\
\text { dysfunctional larynx }\end{array}$ \\
\hline$\underset{[34]}{\text { Succo, } 2016}$ & $\begin{array}{l}\text { Retrospective } \\
\text { cohort study }\end{array}$ & 555 & $\begin{array}{l}\text { pT3- } \\
\text { pT4a }\end{array}$ & OPHL & $\begin{array}{l}84,6 \% / 5 \text { ys } \\
\text { pT3 } 87,8 \% \\
\text { pT4a } 71,2 \%\end{array}$ & $\begin{array}{l}\text { DFS } 84,2 \% \\
\text { pT3 } 87,9 \% \\
\text { pT4a } 68,1 \%\end{array}$ & $\begin{array}{l}\text { LRC } 86,3 \% \\
\text { pT3 } 89,7 \% \\
\text { pT4a } 71,7 \%\end{array}$ & $\begin{array}{l}\text { LFP } 91,2 \% \\
\text { pT4a } 78,0 \% \\
\text { LFS } 93,3 \%\end{array}$ & $\begin{array}{l}\text { Evidence supports open partial } \\
\text { laryngectomy for selected } \\
\text { patients with } T 4 \text { a cancers with } \\
\text { anterior extension }\end{array}$ \\
\hline
\end{tabular}

$\mathrm{YS}=$ years, $\mathrm{PZ}=$ patients, $\mathrm{OS}=$ overall survival, $\mathrm{DFS}=$ disease free-survival, $\mathrm{DSS}=$ disease specific survival, $\mathrm{LP}=$ larynx preservation, LFI = laryngectomy free interval, LEDFS = laryngoesophageal dysfunction-free survival 
Table 3: Acute and delayed toxicities

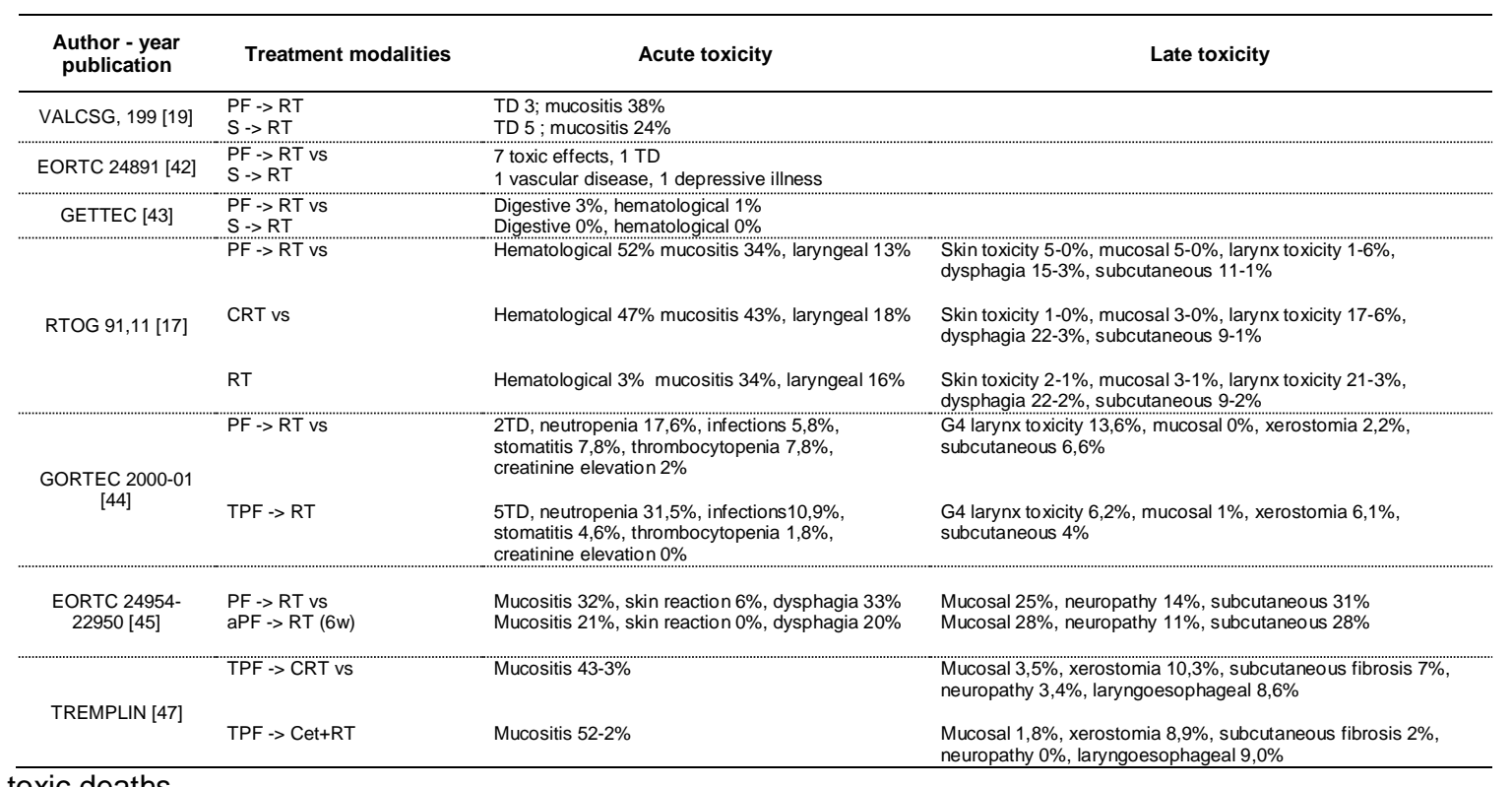

$\mathrm{TD}=$ toxic deaths 
Table 4 Studies analyzing OPHL potentiality also for advanced laryngeal cancer

\begin{tabular}{|c|c|c|c|c|c|c|c|c|c|c|}
\hline Author year & $\mathbf{N}$ & $\begin{array}{l}\text { Cancer } \\
\text { staging }\end{array}$ & Treatment & os & DSS e DFS & LC/LRC & LFP & LFS & $\%$ Complications & \% Recurrence \\
\hline $\begin{array}{c}\text { Bocca, } 1983 \\
{[59]}\end{array}$ & 467 & T2-T4a & OPHL type I & OS / 5 ys $75,0 \%$ & & & & & & \\
\hline $\begin{array}{l}\text { Chevalier, } \\
1997 \text { [60] }\end{array}$ & 61 & $\begin{array}{l}\quad \text { T1-T4a } \\
\text { T1 } 2 \\
\text { T2 } 41 \\
\text { T3 } 14 \\
\text { T4 } 4\end{array}$ & OPHL type II & $\begin{array}{l}\text { OS / } 3 \text { ys } 83 \% \\
\text { OS / } 5 \text { ys } 79 \%\end{array}$ & & & & & & $3,0 \%$ \\
\hline $\begin{array}{l}\text { Laccourreye, } \\
1998 \text { [61] }\end{array}$ & 60 & T3-T4a & $\begin{array}{l}\text { Neo-adjuvant CT } \\
\text { - OPHL type II }\end{array}$ & $\begin{array}{l}87,9 \% \text { / } 3 \text { ys } \\
72,7 \% / 5 \text { ys }\end{array}$ & & $98,3 \%$ & $91,7 \%$ & & $8,3 \%$ local failure & \\
\hline $\begin{array}{l}\text { De Vincentiis, } \\
1998 \text { [62] }\end{array}$ & 149 & & $\begin{array}{l}\text { OPHL type II } \\
\text { (CHP 98 pz } \\
\text { CHEP } 51 \text { pz) }\end{array}$ & $\begin{array}{l}2 \text { groups: } \\
\text { OS } 1^{\circ} 88,1 \% \\
\text { OS } 2^{\circ} 95,0 \%\end{array}$ & & & $98 \%$ & & & $6,0 \%$ \\
\hline Bron, 2000 [63] & 69 & $\begin{array}{l}\quad \text { T1-T4a } \\
\text { pT1 10 } \\
\text { pT2 } 30 \\
\text { pT3 9 } \\
\text { pT4 5 } \\
\text { local } \\
\text { relapse15 }\end{array}$ & $\begin{array}{c}\text { OPHL type II } \\
\text { 13\% adjuvant RT }\end{array}$ & $\begin{array}{l}\text { OS / } 5 \text { ys } 66,5 \% \\
\text { - glottic : } 69,1 \% \\
\text { - supraglottic : } \\
45,6 \%\end{array}$ & $\begin{array}{l}\text { DSS } / 5 \text { ys } \\
80,1 \% \\
\text { - glottic : } 83,2 \% \\
\text { - supraglottic : } \\
51,4 \%\end{array}$ & $\begin{array}{l}\text { LC/5 ys } 84,0 \% \\
\text { LCR no RT Pz } \\
94,5 \%\end{array}$ & & $87,0 \%$ & $49,1 \%$ & $6,1 \%$ \\
\hline $\begin{array}{l}\text { Gallo, } 2005 \\
\text { [64] }\end{array}$ & 253 & $\begin{array}{l}\text { T1-T4a } \\
\text { T1 } 27 \\
\text { T2 } 147 \\
\text { T3 } 64 \\
\text { T4 } 15\end{array}$ & $\begin{array}{l}\text { OPHL type II } \\
180 \mathrm{CHP} \\
73 \mathrm{CHEP}\end{array}$ & $\begin{array}{l}85,8 \% / 3 \text { ys } \\
79,1 \% / 5 \text { ys } \\
57,6 \% / 10 \text { ys } \\
57,6 \% / 16 \text { ys }\end{array}$ & & LRC $91,3 \%$ & $92,1 \%$ & & & $8,7 \%$ \\
\hline Lima, 2005 [65] & 43 & $\begin{array}{l}\text { T3-T4a } \\
\text { glottic }\end{array}$ & $\begin{array}{l}\text { OPHL type II } \\
\text { (CHEP) }\end{array}$ & & $\begin{array}{l}\text { DSS } / 5 \text { ys } \\
78,0 \% \\
\text { DFS / } 5 \text { ys } \\
83,0 \%\end{array}$ & $\begin{array}{l}\text { LRC / } 5 \text { ys } \\
85,0 \%\end{array}$ & & & $25,5 \%$ & \\
\hline $\begin{array}{c}\text { Laudadio, } 2006 \\
\text { [66] }\end{array}$ & 206 & $\begin{array}{l}\text { T1b-T4a } \\
\text { T1b 66 } \\
\text { T2 } 89 \\
\text { T3 46 } \\
\text { T4 5 }\end{array}$ & $\begin{array}{l}\text { OPHL Type II } \\
9,2 \% \text { CHP } \\
90,8 \% \text { CHEP }\end{array}$ & $\begin{array}{l}\text { pT3 } 88,7 \% \\
\text { pT4 78,9\% }\end{array}$ & $\begin{array}{l}\text { DFS / } 3 \text { ys } \\
85,4 \% \\
\text { DFS / } 5 \text { ys } \\
85,0 \% \\
\text { pT3 } 77,6 \% \\
\text { pT } 4 \text { a } 53,8 \%\end{array}$ & & & & & $15,0 \%$ \\
\hline $\begin{array}{c}\text { Rizzotto, } 2015 \\
\text { [67] }\end{array}$ & 115 & $\begin{array}{l}\text { T2-T4a } \\
\text { pT2 14 } \\
\text { pT3 50 } \\
\text { pT4a 51 }\end{array}$ & OPHL Type III & $\begin{array}{l}78,9 \% / 5 y s \\
\text { pT4a } 80,4 \%\end{array}$ & $\begin{array}{l}\text { DFS } 68,5 \% / 5 \\
\text { ys } \\
\text { pT4a } 60,8 \%\end{array}$ & $\begin{array}{l}69,6 \% / 5 \text { ys } \\
\text { pT4a } 62,7 \%\end{array}$ & & $\begin{array}{l}\text { LFP } 78,3 \% \\
\text { pT4a } 59,3 \%\end{array}$ & $\begin{array}{l}6,1 \% \text { acute } \\
24,4 \% \text { late }\end{array}$ & \\
\hline $\begin{array}{c}\text { Succo, } 2016 \\
{[34]}\end{array}$ & 555 & рТ3-рТ4a & $\mathrm{OPHL}$ & $84,6 \%$ / 5 ys & pT4a $68,1 \%$ & pT4a $71,7 \%$ & pT4a $78,0 \%$ & $93,3 \%$ & & \\
\hline
\end{tabular}

LFP = laryngeal function preservation, LFS = laryngectomy free survival, LC = local control 
Table 5 Complications, survival outcomes and prognostic risk factors in patients with salvage surgery after organ-sparing protocols for SCC of larynx

\begin{tabular}{|c|c|c|c|c|c|c|c|c|c|}
\hline $\begin{array}{l}\text { Author - year } \\
\text { publication }\end{array}$ & $\begin{array}{c}\mathrm{N}^{\circ} \text { of } \\
\text { patients }\end{array}$ & $\begin{array}{l}\text { Previous } \\
\text { treatment }\end{array}$ & $\begin{array}{l}\text { Salvage } \\
\text { surgery }\end{array}$ & $\begin{array}{l}\text { Complica } \\
\text { tions }\end{array}$ & Fistula & LR & os & DSS & Risk factors \\
\hline Paleri, 2011 [68] & 350 & CRT & SPL & & & $87 \% / 2 y s$ & $83 \% / 3 y s$ & $91 \% / 2 y s$ & \\
\hline Putten, 2011 [69] & 120 & CRT & STL & & & $70 \% / 5 y s$ & $50 \% / 5 y s$ & $58 \% / 5 y s$ & $\begin{array}{l}\text { Risk factors: level of albumin and } \\
\text { hemoglobin, } \mathrm{N}_{+}\end{array}$ \\
\hline Klozar, 2012 [70] & 208 & CRT & STL & & $34 \%$ & & & & \\
\hline Erdag, 2013 [71] & 36 & & STL & & $50 \%$ & & & & \\
\hline $\begin{array}{c}\text { Sewnaik, } 2012 \\
{[72]}\end{array}$ & 24 & CRT & STL & $92 \%$ & & & & & \\
\hline Patel, 2013 [73] & 359 & CRT & STL & & $27 \%$ & & & & \\
\hline $\begin{array}{l}\text { De Vincentiis, } \\
2013 \text { [74] }\end{array}$ & 68 & (C)RT - TLM & $\begin{array}{l}\text { SPL (23 pz) } \\
\text { STL ( } 45 \mathrm{pz})\end{array}$ & & & & & & $\begin{array}{l}\text { OS and DFS }<S T L \text { than } S P L \text { (prognostic } \\
\text { factor involvement of resection margins) }\end{array}$ \\
\hline $\begin{array}{l}\text { Santoro, } 2013 \\
{[75]}\end{array}$ & 75 & RT & $\begin{array}{l}\text { SPL }(16 \%) \\
\text { STL }(84 \%)\end{array}$ & & $32,7 \%$ & & & & $\begin{array}{l}\text { OS and DFS }<\text { STL than SPL (prognostic } \\
\text { factor } r T \text { ) }\end{array}$ \\
\hline Li, 2013 [76] & 100 & CRT & STL & & & $70 \% / 5$ ys & & $\begin{array}{l}55-70 \% / \\
5 y s\end{array}$ & \\
\hline $\begin{array}{c}\text { Basheeth, } 2013 \\
{[37]}\end{array}$ & 45 & CRT & STL & $44 \%$ & & & & & \\
\hline Sayles, 2014 [77] & 33 studies & $\begin{array}{c}\text { CRT } \\
\text { RT alone }\end{array}$ & STL & & $\begin{array}{c}34 \% \\
22,8 \%\end{array}$ & & & & \\
\hline Sayles, 2014 [77] & 33 studies & CRT & $\begin{array}{l}\text { PTL } \\
\text { STL }\end{array}$ & & $\begin{array}{l}14,3 \% \\
27,6 \%\end{array}$ & & & & \\
\hline $\begin{array}{l}\text { Timmermans } \\
2014[78]\end{array}$ & 98 & CRT & STL & & $26 \%$ & & & & \\
\hline Powell, 2014 [79] & 45 & CRT & STL & & $22 \%$ & & & & \\
\hline Süslü, 2015 [80] & 151 & CRT & STL & & $13 \%$ & & & & \\
\hline Busoni, 2015 [81] & 86 & $\begin{array}{c}\text { PTL } \\
\text { STL post-RT } \\
\text { STL post-CRT }\end{array}$ & & & $\begin{array}{c}19 \% \\
28,6 \% \\
30,3 \%\end{array}$ & & & & \\
\hline Putten, 2015 [82] & 22 & CRT & STL & $73 \%$ & $23 \%$ & $58 \% / 5 y s$ & $27 \% / 5 y s$ & $36 \% / 5$ ys & \\
\hline Wulff, 2016 [83] & 142 & CRT & STL & $60 \%$ & $41,6 \%$ & & $37,7 \% / 5 y s$ & $54,9 \% / 5 y s$ & $\mathrm{~N}+$ and positive margins \\
\hline
\end{tabular}

$\mathrm{STL}=$ salvage total laryngectomy, SPL salvage partial laryngectomy 
Table 6 Comparison of PCF in patients with salvage laryngectomy with and without flap reinforcement

\begin{tabular}{|c|c|c|c|c|c|}
\hline $\begin{array}{l}\text { Author - } \\
\text { year } \\
\text { publication }\end{array}$ & $\begin{array}{c}\mathbf{N}^{\circ} \text { of } \\
\text { patients }\end{array}$ & Treatment & Fistula with flap & $\begin{array}{l}\text { Fistula without } \\
\text { flap }\end{array}$ & Results and conclusions \\
\hline $\begin{array}{l}\text { Patel, } 2009 \\
{[84]}\end{array}$ & 359 & $\begin{array}{l}\text { PMF } \\
\text { FVT }\end{array}$ & $\begin{array}{l}15 \% \\
25 \%\end{array}$ & $34 \%$ & $\begin{array}{l}\text { With PMF reinforcement, PCFrate after } \\
\text { salvage laryngectomy dropped to } 0 \% \text { in } \\
\text { this study }\end{array}$ \\
\hline $\begin{array}{l}\text { Busoni, } 2013 \\
\quad[81]\end{array}$ & 20 & $\begin{array}{l}\text { Conservative } \\
\text { FVT }\end{array}$ & & & $\begin{array}{l}\text { Fistula after PTL } \rightarrow \text { conservative } \\
\text { treatment } \\
\text { Fistula after STL } \rightarrow \text { flaps }\end{array}$ \\
\hline $\begin{array}{c}\text { Santoro, } 2013 \\
{[75]}\end{array}$ & 29 & $\begin{array}{c}\text { Conservative } \\
\text { FVT }\end{array}$ & $\begin{array}{c}80,5 \% \\
8,3 \% \text { PFM } \\
21 \% \text { local flaps }\end{array}$ & $34 \%$ & Flaps reduce the risk of fistula \\
\hline $\begin{array}{l}\text { Powell, } 2014 \\
\quad[79]\end{array}$ & 45 & FVT/PMF & $0 \%$ & $26 \%$ & $\begin{array}{l}\text { lower rate of PCF with tissue transfer } \\
\text { compared with primary closure of the } \\
\text { neopharynx. }\end{array}$ \\
\hline $\begin{array}{l}\text { Sayles, } 2014 \\
\quad[77]\end{array}$ & 33 studies & Onlay flap & $10 \%$ & $28 \%$ & $\begin{array}{l}\text { Prophylactic flaps used in an "onlay" } \\
\text { technique reduce fistula incidence in } \\
\text { STL }\end{array}$ \\
\hline $\begin{array}{c}\text { Paleri, } 2014 \\
\quad[35]\end{array}$ & 591 & & & & Flaps reduce the risk of fistula \\
\hline $\begin{array}{l}\text { Anschutz, } \\
2016 \text { [85] }\end{array}$ & 48 & PMMF & $0 \%$ & $42,1 \%$ & $\begin{array}{l}\text { PMMIF is useful to prevent PCF in STL } \\
\text { following CRT. }\end{array}$ \\
\hline
\end{tabular}

$\mathrm{PMF}=$ pectoralis myofascial flap, $\mathrm{FVT}=$ free vascularized tissue 


\section{Bibliography}

1. Fu X, Zhou Q, Zhang X. Efficacy Comparison Between Total Laryngectomy and Nonsurgical Organ-Preservation Modalities in Treatment of Advanced Stage Laryngeal Cancer: A Meta-Analysis. Medicine (Baltimore). 2016;95(14):e3142.

doi:10.1097/MD.0000000000003142.

2. Tomeh C, Holsinger FC. Laryngeal cancer. Curr Opin Otolaryngol Head Neck Surg. 2014;22(2):147-53. doi:10.1097/MOO.0000000000000032.

3. Stankovic M, Milisavljevic D, Stojanov D, Zivic M, Zivaljevic S, Stankovic I et al. Influential factors, complications and survival rate of primary and salvage total laryngectomy for advanced laryngeal cancer. Coll Antropol. 2012;36 Suppl 2:7-12.

4. Pfister DG, Spencer S, Brizel DM, Burtness B, Busse PM, Caudell JJ et al. Head and neck cancers, Version 2.2014. Clinical practice guidelines in oncology. J Natl Compr Canc Netw. 2014;12(10):1454-87.

5. TNM Classification of Malignant Tumours. Seventh ed. ed. New York: Wiley-Liss; 2010.

6. Gussenbauer C. Über die erste durch Th. Billroth am Menschen ausgeführte Kehlkopf Exstirpation und die Anwendung eines künstlichen Kehlkopfes Arch Klin Chir.

1874;17(2):343-56.

7. Christiansen H, Wolff HA, Hess CF, Rodel RM, Steiner W, Matthias C. Larynx preservation clinical trial design: key issues and recommendations--a consensus panel summary: in regard to Lefebvre et al., for the larynx preservation consensus panel (Int $\mathrm{J}$ Radiat Oncol Biol Phys 2009;73:1293-1303). Int J Radiat Oncol Biol Phys. 2009;75(2):633; author reply -4. doi:10.1016/j.jijobp.2009.05.062.

8. Induction chemotherapy plus radiation compared with surgery plus radiation in patients with advanced laryngeal cancer. The Department of Veterans Affairs Laryngeal Cancer Study Group. N Engl J Med. 1991;324(24):1685-90. doi:10.1056/NEJM199106133242402. 9. Forastiere AA, Goepfert H, Maor M, Pajak TF, Weber R, Morrison W et al. Concurrent chemotherapy and radiotherapy for organ preservation in advanced laryngeal cancer. $\mathrm{N}$ Engl J Med. 2003;349(22):2091-8. doi:10.1056/NEJMoa031317.

10. Ang KK. Larynx preservation clinical trial design: summary of key recommendations of a consensus panel. Oncologist. 2010;15 Suppl 3:25-9. doi:10.1634/theoncologist.2010-S325.

11. Associazione Italiana di Oncologia Medica. Linee guida dei Tumori della Testa e del Collo. AIOM; 2015.

12. American Society of Clinical O, Pfister DG, Laurie SA, Weinstein GS, Mendenhall WM, Adelstein DJ et al. American Society of Clinical Oncology clinical practice guideline for the use of larynx-preservation strategies in the treatment of laryngeal cancer. J Clin Oncol. 2006;24(22):3693-704. doi:10.1200/JCO.2006.07.4559.

13. Hoffman HT, Porter K, Karnell LH, Cooper JS, Weber RS, Langer CJ et al. Laryngeal cancer in the United States: changes in demographics, patterns of care, and survival. Laryngoscope. 2006;116(9 Pt 2 Suppl 111):1-13.

doi:10.1097/01.mlg.0000236095.97947.26.

14. Rosenthal DI, Mohamed AS, Weber RS, Garden AS, Sevak PR, Kies MS et al. Longterm outcomes after surgical or nonsurgical initial therapy for patients with T4 squamous cell carcinoma of the larynx: A 3-decade survey. Cancer. 2015;121(10):1608-19. doi:10.1002/cncr.29241.

15. Reizenstein JA, Holmberg L, Bergqvist M, Linder A, Ekman S, Loden B et al. Time trends in T3 to T4 laryngeal cancer: a population-based long-term analysis. Head Neck. 2014;36(12):1727-31. doi:10.1002/hed.23524. 
16. Sherman EJ, Fisher SG, Kraus DH, Zelefsky MJ, Seshan VE, Singh B et al. TALK score: Development and validation of a prognostic model for predicting larynx preservation outcome. Laryngoscope. 2012;122(5):1043-50. doi:10.1002/lary.23220.

17. Forastiere AA, Zhang Q, Weber RS, Maor MH, Goepfert H, Pajak TF et al. Long-term results of RTOG 91-11: a comparison of three nonsurgical treatment strategies to preserve the larynx in patients with locally advanced larynx cancer. J Clin Oncol. 2013;31(7):845-52. doi:10.1200/JCO.2012.43.6097.

18. Lefebvre JL. Larynx preservation. Curr Opin Oncol. 2012;24(3):218-22. doi:10.1097/CCO.0b013e3283523c95.

19. Timmermans AJ, de Gooijer CJ, Hamming-Vrieze O, Hilgers FJ, van den Brekel MW. T3-T4 laryngeal cancer in The Netherlands Cancer Institute; 10-year results of the consistent application of an organ-preserving/-sacrificing protocol. Head Neck. 2015;37(10):1495-503. doi:10.1002/hed.23789.

20. Francis E, Matar N, Khoueir N, Nassif C, Farah C, Haddad A. T4a laryngeal cancer survival: retrospective institutional analysis and systematic review. Laryngoscope. 2014;124(7):1618-23. doi:10.1002/lary.24557.

21. Dabholkar JP, Kapre NM, Gupta HK. Results of Voice Rehabilitation With Provox Prosthesis and Factors Affecting the Voice Quality. J Voice. 2015;29(6):777 e1-8. doi:10.1016/j.jvoice.2015.01.003.

22. Silver CE, Beitler JJ, Shaha AR, Rinaldo A, Ferlito A. Current trends in initial management of laryngeal cancer: the declining use of open surgery. Eur Arch Otorhinolaryngol. 2009;266(9):1333-52. doi:10.1007/s00405-009-1028-2.

23. Elmiyeh B, Dwivedi RC, Jallali N, Chisholm EJ, Kazi R, Clarke PM et al. Surgical voice restoration after total laryngectomy: an overview. Indian J Cancer. 2010;47(3):239-47. doi:10.4103/0019-509X.64707.

24. Serafini I. [Reconstructive laryngectomy]. Rev Laryngol Otol Rhinol (Bord). 1972;93(1):23-38.

25. Laccourreye O, Brasnu D, Jouffre V, Couloigner V, Naudo P, Laccourreye H. [Supracricoid partial laryngectomy extended to the anterior arch of the cricoid with tracheo-cricohyoido-epiglottopexy. Oncologic and functional results]. Ann Otolaryngol Chir Cervicofac. 1996;113(1):15-9.

26. Majer EH, Rieder W. [Technic of laryngectomy permitting the conservation of respiratory permeability (cricohyoidopexy)]. Ann Otolaryngol. 1959;76:677-81.

27. Piquet JJ, Desaulty A, Decroix G. [Crico-hyoido-epiglotto-pexy. Surgical technic and functional results]. Ann Otolaryngol Chir Cervicofac. 1974;91(12):681-6.

28. Labayle J, Bismuth R. [Total laryngectomy with reconstitution]. Ann Otolaryngol Chir Cervicofac. 1971;88(4):219-28.

29. Tibbetts KM, Tan M. Role of Advanced Laryngeal Imaging in Glottic Cancer: Early

Detection and Evaluation of Glottic Neoplasms. Otolaryngol Clin North Am.

2015;48(4):565-84. doi:10.1016/j.otc.2015.04.004.

30. Lee HS, Chun BG, Kim SW, Kim ST, Oh JH, Hong JC et al. Transoral laser microsurgery for early glottic cancer as one-stage single-modality therapy. Laryngoscope. 2013;123(11):2670-4. doi:10.1002/lary.24080.

31. Abouyared M, Ojo R, Fundakowski C, Lo K, Sargi Z. Transoral laser microsurgery in previously irradiated patients with laryngeal cancer. Am J Otolaryngol. 2014;35(3):279-85. doi:10.1016/j.amjoto.2014.03.004.

32. Peretti G, Piazza C, Mora F, Garofolo S, Guastini L. Reasonable limits for transoral laser microsurgery in laryngeal cancer. Curr Opin Otolaryngol Head Neck Surg.

2016;24(2):135-9. doi:10.1097/MOO.0000000000000240.

33. Forastiere AA, Weber RS, Trotti A. Organ Preservation for Advanced Larynx Cancer: Issues and Outcomes. J Clin Oncol. 2015;33(29):3262-8. doi:10.1200/JCO.2015.61.2978. 
34. Succo G, Crosetti E, Bertolin A, Lucioni M, Arrigoni G, Panetta V et al. Benefits and drawbacks of open partial horizontal laryngectomies, Part B: Intermediate and selected advanced stage laryngeal carcinoma. Head Neck. 2016;38 Suppl 1:E649-57. doi:10.1002/hed.24064.

35. Paleri V, Drinnan M, van den Brekel MW, Hinni ML, Bradley PJ, Wolf GT et al. Vascularized tissue to reduce fistula following salvage total laryngectomy: a systematic review. Laryngoscope. 2014;124(8):1848-53. doi:10.1002/lary.24619.

36. Agra IM, Ferlito A, Takes RP, Silver CE, Olsen KD, Stoeckli SJ et al. Diagnosis and treatment of recurrent laryngeal cancer following initial nonsurgical therapy. Head Neck. 2012;34(5):727-35. doi:10.1002/hed.21739.

37. Basheeth N, O'Leary G, Sheahan P. Elective neck dissection for no neck during salvage total laryngectomy: findings, complications, and oncological outcome. JAMA Otolaryngol Head Neck Surg. 2013;139(8):790-6. doi:10.1001/jamaoto.2013.3995. 38. Ridha H, Clarke PM, Wood SH. Re: "Long-term oral intake through a salivary bypass tube with chronic pharyngocutaneous fistula". Am J Otolaryngol. 2013;34(5):615-6. doi:10.1016/j.amjoto.2013.03.009.

39. Lopez F, Obeso S, Camporro D, Fueyo A, Suarez C, Llorente JL. Outcomes following pharyngolaryngectomy with fasciocutaneous free flap reconstruction and salivary bypass tube. Laryngoscope. 2013;123(3):591-6. doi:10.1002/lary.23695.

40. Denaro N, Russi EG, Lefebvre JL, Merlano MC. A systematic review of current and emerging approaches in the field of larynx preservation. Radiother Oncol. 2013. doi:10.1016/j.radonc.2013.08.016.

41. Crosetti E, Fantini M, Arrigoni G, Salonia L, Lombardo A, Atzori A et al. Telephonic voice intelligibility after laryngeal cancer treatment: is therapeutic approach significant? Eur Arch Otorhinolaryngol. 2016. doi:10.1007/s00405-016-4217-9.

42. Lefebvre JL, Rolland F, Tesselaar M, Bardet E, Leemans CR, Geoffrois L et al. Phase 3 randomized trial on larynx preservation comparing sequential vs alternating chemotherapy and radiotherapy. J Natl Cancer Inst. 2009;101(3):142-52. doi:10.1093/jnci/djn460.

43. Richard JM, Sancho-Garnier H, Pessey JJ, Luboinski B, Lefebvre JL, Dehesdin D et al. Randomized trial of induction chemotherapy in larynx carcinoma. Oral Oncol. 1998;34(3):224-8.

44. Pointreau Y, Garaud P, Chapet S, Sire C, Tuchais C, Tortochaux J et al. Randomized trial of induction chemotherapy with cisplatin and 5-fluorouracil with or without docetaxel for larynx preservation. J Natl Cancer Inst. 2009;101(7):498-506. doi:10.1093/jnci/djp007. 45. Lefebvre JL, Chevalier D, Luboinski B, Kirkpatrick A, Collette L, Sahmoud T. Larynx preservation in pyriform sinus cancer: preliminary results of a European Organization for Research and Treatment of Cancer phase III trial. EORTC Head and Neck Cancer Cooperative Group. J Natl Cancer Inst. 1996;88(13):890-9.

46. Posner MR, Hershock DM, Blajman CR, Mickiewicz E, Winquist E, Gorbounova V et al. Cisplatin and fluorouracil alone or with docetaxel in head and neck cancer. N Engl J Med. 2007;357(17):1705-15. doi:10.1056/NEJMoa070956.

47. Lefebvre JL, Pointreau Y, Rolland F, Alfonsi M, Baudoux A, Sire C et al. Induction chemotherapy followed by either chemoradiotherapy or bioradiotherapy for larynx preservation: the TREMPLIN randomized phase II study. J Clin Oncol. 2013;31(7):853-9. doi:10.1200/JCO.2012.42.3988.

48. Prades JM, Lallemant B, Garrel R, Reyt E, Righini C, Schmitt T et al. Randomized phase III trial comparing induction chemotherapy followed by radiotherapy to concomitant chemoradiotherapy for laryngeal preservation in T3M0 pyriform sinus carcinoma. Acta Otolaryngol. 2010;130(1):150-5. doi:10.3109/00016480902914080. 
49. Bussu F, Paludetti G, Almadori G, De Virgilio A, Galli J, Micciche F et al. Comparison of total laryngectomy with surgical (cricohyoidopexy) and nonsurgical organ-preservation modalities in advanced laryngeal squamous cell carcinomas: A multicenter retrospective analysis. Head Neck. 2013;35(4):554-61. doi:10.1002/hed.22994.

50. Dziegielewski PT, O'Connell DA, Klein M, Fung C, Singh P, Alex Mlynarek M et al. Primary total laryngectomy versus organ preservation for T3/T4a laryngeal cancer: a population-based analysis of survival. J Otolaryngol Head Neck Surg. 2012;41 Suppl 1:S56-64.

51. Grover S, Swisher-McClure S, Mitra N, Li J, Cohen RB, Ahn PH et al. Total Laryngectomy Versus Larynx Preservation for T4a Larynx Cancer: Patterns of Care and Survival Outcomes. Int J Radiat Oncol Biol Phys. 2015;92(3):594-601. doi:10.1016/j.jijobp.2015.03.004.

52. Timmermans AJ, van Dijk BA, Overbeek LI, van Velthuysen $\mathrm{ML}$, van Tinteren $\mathrm{H}$, Hilgers FJ et al. Trends in treatment and survival for advanced laryngeal cancer: A 20-year population-based study in The Netherlands. Head Neck. 2016;38 Suppl 1:E1247-55. doi:10.1002/hed.24200.

53. Timme DW, Jonnalagadda S, Patel R, Rao K, Robbins KT. Treatment Selection for T3/T4a Laryngeal Cancer: Chemoradiation Versus Primary Surgery. Ann Otol Rhinol Laryngol. 2015;124(11):845-51. doi:10.1177/0003489415588130.

54. Luo XN, Chen LS, Zhang SY, Lu ZM, Huang Y. Effectiveness of chemotherapy and radiotherapy for laryngeal preservation in advanced laryngeal cancer: a meta-analysis and systematic review. Radiol Med. 2015;120(12):1153-69. doi:10.1007/s11547-015-0547-8. 55. Rodrigo JP, Lopez F, Llorente JL, Alvarez-Marcos C, Suarez C. [Results of total laryngectomy as treatment for locally advanced laryngeal cancer in the organ-preservation era]. Acta Otorrinolaringol Esp. 2015;66(3):132-8. doi:10.1016/j.otorri.2014.06.001. 56. Gorphe P, Matias M, Moya-Plana A, Tabarino F, Blanchard P, Tao Y et al. Results and Survival of Locally Advanced AJCC 7th Edition T4a Laryngeal Squamous Cell Carcinoma Treated with Primary Total Laryngectomy and Postoperative Radiotherapy. Ann Surg Oncol. 2016;23(8):2596-601. doi:10.1245/s10434-016-5217-0.

57. Sanabria A, Chaves AL, Kowalski LP, Wolf GT, Saba NF, Forastiere AA et al. Organ preservation with chemoradiation in advanced laryngeal cancer: The problem of generalizing results from randomized controlled trials. Auris Nasus Larynx. 2016. doi:10.1016/j.anl.2016.06.005.

58. Al-Gilani M, Skillington SA, Kallogjeri D, Haughey B, Piccirillo JF. Surgical vs Nonsurgical Treatment Modalities for T3 Glottic Squamous Cell Carcinoma. JAMA Otolaryngol Head Neck Surg. 2016. doi:10.1001/jamaoto.2016.1609.

59. Bocca E, Pignataro O, Oldini C. Supraglottic laryngectomy: 30 years of experience. Ann Otol Rhinol Laryngol. 1983;92(1 Pt 1):14-8.

60. Chevalier D, Laccourreye O, Brasnu D, Laccourreye H, Piquet JJ.

Cricohyoidoepiglottopexy for glottic carcinoma with fixation or impaired motion of the true vocal cord: 5-year oncologic results with 112 patients. Ann Otol Rhinol Laryngol. 1997;106(5):364-9.

61. Laccourreye O, Brasnu D, Biacabe B, Hans S, Seckin S, Weinstein G. Neo-adjuvant chemotherapy and supracricoid partial laryngectomy with cricohyoidopexy for advanced endolaryngeal carcinoma classified as T3-T4: 5-year oncologic results. Head Neck. 1998;20(7):595-9.

62. de Vincentiis M, Minni A, Gallo A, Di Nardo A. Supracricoid partial laryngectomies: oncologic and functional results. Head Neck. 1998;20(6):504-9.

63. Bron L, Brossard E, Monnier P, Pasche P. Supracricoid partial laryngectomy with cricohyoidoepiglottopexy and cricohyoidopexy for glottic and supraglottic carcinomas. Laryngoscope. 2000;110(4):627-34. doi:10.1097/00005537-200004000-00017. 
64. Gallo A, Manciocco V, Simonelli M, Pagliuca G, D'Arcangelo E, de Vincentiis M. Supracricoid partial laryngectomy in the treatment of laryngeal cancer: univariate and multivariate analysis of prognostic factors. Arch Otolaryngol Head Neck Surg. 2005;131(7):620-5. doi:10.1001/archotol.131.7.620.

65. Lima RA, Freitas EQ, Dias FL, Barbosa MM, Kligerman J, Soares JR et al. Supracricoid laryngectomy with cricohyoidoepiglottopexy for advanced glottic cancer. Head Neck. 2006;28(6):481-6. doi:10.1002/hed.20361.

66. Laudadio P, Presutti L, Dall'olio D, Cunsolo E, Consalici R, Amorosa L et al. Supracricoid laryngectomies: long-term oncological and functional results. Acta Otolaryngol. 2006;126(6):640-9. doi:10.1080/00016480500469024.

67. Rizzotto G, Crosetti E, Lucioni M, Bertolin A, Monticone V, Sprio AE et al. Oncological outcomes of supratracheal laryngectomy: A critical analysis. Head Neck. 2015;37(10):1417-24. doi:10.1002/hed.23773.

68. Paleri V, Thomas L, Basavaiah N, Drinnan M, Mehanna H, Jones T. Oncologic outcomes of open conservation laryngectomy for radiorecurrent laryngeal carcinoma: a systematic review and meta-analysis of English-language literature. Cancer.

2011;117(12):2668-76. doi:10.1002/cncr.25831.

69. van der Putten L, de Bree R, Kuik DJ, Rietveld DH, Buter J, Eerenstein SE et al. Salvage laryngectomy: oncological and functional outcome. Oral Oncol. 2011;47(4):296301. doi:10.1016/j.oraloncology.2011.02.002.

70. Klozar J, Cada Z, Koslabova E. Complications of total laryngectomy in the era of chemoradiation. Eur Arch Otorhinolaryngol. 2012;269(1):289-93. doi:10.1007/s00405-0111598-7.

71. Erdag MA, Arslanoglu S, Onal K, Songu M, Tuylu AO. Pharyngocutaneous fistula following total laryngectomy: multivariate analysis of risk factors. Eur Arch Otorhinolaryngol. 2013;270(1):173-9. doi:10.1007/s00405-012-2111-7.

72. Sewnaik A, Keereweer S, Al-Mamgani A, Baatenburg de Jong RJ, Wieringa $M H$, Meeuwis CA et al. High complication risk of salvage surgery after chemoradiation failures. Acta Otolaryngol. 2012;132(1):96-100. doi:10.3109/00016489.2011.617779.

73. Patel UA, Moore BA, Wax M, Rosenthal E, Sweeny L, Militsakh ON et al. Impact of pharyngeal closure technique on fistula after salvage laryngectomy. JAMA Otolaryngol Head Neck Surg. 2013;139(11):1156-62. doi:10.1001/jamaoto.2013.2761.

74. de Vincentiis M, De Virgilio A, Bussu F, Gallus R, Gallo A, Bastanza G et al. Oncologic results of the surgical salvage of recurrent laryngeal squamous cell carcinoma in a multicentric retrospective series: emerging role of supracricoid partial laryngectomy. Head Neck. 2015;37(1):84-91. doi:10.1002/hed.23563.

75. Santoro R, Meccariello G, Mannelli G, Bini B, Paiar F, Gallo O. Surgical options in radiotherapy-failed early glottic cancer. Eur Arch Otorhinolaryngol. 2014;271(4):777-85. doi:10.1007/s00405-013-2583-0.

76. Li M, Lorenz RR, Khan MJ, Burkey BB, Adelstein DJ, Greskovich JF, Jr. et al. Salvage laryngectomy in patients with recurrent laryngeal cancer in the setting of nonoperative treatment failure. Otolaryngol Head Neck Surg. 2013;149(2):245-51.

doi:10.1177/0194599813486257.

77. Sayles M, Grant DG. Preventing pharyngo-cutaneous fistula in total laryngectomy: a systematic review and meta-analysis. Laryngoscope. 2014;124(5):1150-63.

doi:10.1002/lary.24448.

78. Timmermans AJ, Lansaat L, Theunissen EA, Hamming-Vrieze O, Hilgers FJ, van den Brekel MW. Predictive factors for pharyngocutaneous fistulization after total laryngectomy. Ann Otol Rhinol Laryngol. 2014;123(3):153-61. doi:10.1177/0003489414522972. 
79. Powell J, Ullal UR, Ahmed O, Ragbir M, Paleri V. Tissue transfer to postchemoradiation salvage laryngectomy defects to prevent pharyngocutaneous fistula: single-centre experience. J Laryngol Otol. 2014:1-3. doi:10.1017/S0022215114000504. 80. Suslu N, Senirli RT, Gunaydin RO, Ozer S, Karakaya J, Hosal AS. Pharyngocutaneous fistula after salvage laryngectomy. Acta Otolaryngol. 2015;135(6):615-21. doi:10.3109/00016489.2015.1009639.

81. Busoni M, Deganello A, Gallo O. Pharyngocutaneous fistula following total laryngectomy: analysis of risk factors, prognosis and treatment modalities. Acta Otorhinolaryngol Ital. 2015;35(6):400-5. doi:10.14639/0392-100X-626.

82. Putten L, Bree R, Doornaert PA, Buter J, Eerenstein SE, Rietveld DH et al. Salvage surgery in post-chemoradiation laryngeal and hypopharyngeal carcinoma: outcome and review. Acta Otorhinolaryngol Ital. 2015;35(3):162-72.

83. Wulff NB, Andersen E, Kristensen CA, Sorensen CH, Charabi B, Homoe P. Prognostic factors for survival after salvage total laryngectomy following radiotherapy or chemoradiation failure: a 10-year retrospective longitudinal study in eastern Denmark. Clin Otolaryngol. 2016. doi:10.1111/coa.12726.

84. Patel UA, Keni SP. Pectoralis myofascial flap during salvage laryngectomy prevents pharyngocutaneous fistula. Otolaryngol Head Neck Surg. 2009;141(2):190-5. doi:10.1016/j.otohns.2009.03.024.

85. Anschutz L, Nisa L, Elicin O, Bojaxhiu B, Caversaccio M, Giger R. Pectoralis major myofascial interposition flap prevents postoperative pharyngocutaneous fistula in salvage total laryngectomy. Eur Arch Otorhinolaryngol. 2016;273(11):3943-9. doi:10.1007/s00405016-4049-7. 